\title{
Mechanism of Action of Nikkomycin and the Peptide Transport System of Candida albicans
}

\author{
By PETER J. MCCARTHY, ${ }^{*} \dagger$ PETER F. TROKE ${ }^{2} \ddagger$ AND \\ KEITH GULL ${ }^{1}$ \\ ${ }^{1}$ Biological Laboratories, University of Kent, Canterbury, Kent, UK \\ ${ }^{1}$ Sandoz Research Institute, Vienna, Austria
}

(Received 7 August 1984 ; revised 13 November 1984)

Nikkomycin was found to be a potent growth inhibitor of Candida albicans through competitive inhibition of chitin synthase $\left[K_{\mathrm{i}}=0.16 \mu \mathrm{M}\left(0 \cdot 1 \mu \mathrm{g} \mathrm{ml}^{-1}\right)\right]$. The activity of the peptide-nucleoside drug was antagonized by both peptone and defined peptides. Transported dipeptides were effective antagonists while transported oligopeptides were not. A mutant of $C$. albicans resistant to the effects of nikkomycin through a transport defect was unable to transport dipeptides, while oligopeptide uptake was apparently unaffected. At least two peptide permeases are operational in this organism.

\section{INTRODUCTION}

The nikkomycins are peptide-nucleosides isolated from culture supernatants of Streptomyces tendae Tu 901 (Dahn et al., 1976). In both structure and activity they are closely related to the polyoxins, being inhibitors of the cell wall synthetic enzyme chitin synthase. As peptide derivatives, the nikkomycins are of potential use in the study of peptide permeases: peptide drugs such as L-ethionyl-L-alanine (Marder et al., 1978) and bacilysin (Nisbet \& Payne, 1979a) have been used to show the presence of a single peptide transport system in Saccharomyces cerevisiae. Despite studies by several groups of workers, the number of peptide permeases in the pathogenic fungus Candida albicans has not been fully elucidated. Logan et al. (1979) suggested that multiple permeases may be present; however, Davies (1980) produced evidence for a single system. Recently, further evidence for the presence of multiple permeases has been derived from kinetic analyses (Sarthou et al., 1983). In this communication we report results concerning the uptake of nikkomycin by $C$. albicans and demonstrate its value for the study of peptide permeases.

\section{METHODS}

Organism. Candida albicans 124, obtained from the Sandoz Research Institute, Vienna, was used in all experiments. The organism was maintained on $2 \%(\mathrm{w} / \mathrm{v})$ malt extract plates at $37^{\circ} \mathrm{C}$ and subcultured weekly.

Growth conditions. Unless otherwise stated, two liquid media were used for the cultivation of $C$. albicans: $(a)$ yeast nitrogen base containing $0.5 \%(w / v)$ ammonium sulphate (YNB, Difco) supplemented with $1 \%(w / v)$ glucose, and (b) YNB without ammonium sulphate or amino acids (Difco) supplemented with $2 \%$ (w/v) bactopeptone (Oxoid) and $2 \%(\mathrm{w} / \mathrm{v})$ glucose (YNB/peptone). For batch growth, cells were taken from plates and inoculated into liquid medium to give $10^{5}$ cells ml-1. Growth, at $30^{\circ} \mathrm{C}$ and 120 r.p.m., was followed using an EEL colorimeter with green filter.

Measurement of peptide transport. Cells were grown to mid-exponential phase in YNB/peptone, harvested by centrifugation at $1500 \mathrm{~g}$ and washed three times with PCG $\left(10 \mathrm{~mm}-\mathrm{Na}_{2} \mathrm{HPO}_{4}\right.$-citric acid pH 5.0, supplemented with $0.8 \%$ glucose). The pellet was finally resuspended in a small volume of PCG, stored at $4{ }^{\circ} \mathrm{C}$ and used within $2 \mathrm{~h}$. USA

† Present address : Smith Kline and French Laboratories, 1500 Spring Garden Street, PO Box 7929, PA 19101, $\ddagger$ Present address: Pfizer Central Research, Sandwich, Kent, UK. 
(a) Fluorescamine method (Nisbet \& Payne 1979b). C. albicans blastospores were diluted and incubated at $37^{\circ} \mathrm{C}$ for $10 \mathrm{~min}$. Peptide stocks, prepared in PCG and preincubated at $37^{\circ} \mathrm{C}$, were added to the cells to give a working volume of $10 \mathrm{ml}$ and a cell density equivalent to $1.0 \mathrm{mg}$ dry wt ml-1. Incubation was at $37^{\circ} \mathrm{C}$ with shaking $\left(80\right.$ strokes $\left.\mathrm{min}^{-1}\right)$. Samples $(0.5 \mathrm{ml})$ were removed at timed intervals and filtered through Whatman GF/A filters using a 10-place filtration unit (Hoefer Scientific Instruments, California, USA). The filtrate was collected and its peptide concentration assayed as follows. Samples of peptide solution $(50 \mu \mathrm{l})$ containing up to $250 \mathrm{nmol}$ peptide were diluted with $2.5 \mathrm{ml} 0.1 \mathrm{M}$-sodium tetraborate (adjusted to $\mathrm{pH} 6.2$ with $\mathrm{HCl}$ ). Fluorescamine solution $\left(0.15 \mathrm{mg} \mathrm{ml}^{-1}\right.$ in acetone; $\left.0.5 \mathrm{ml}\right)$ was added with vortexing. The fluorescence of the solution was measured within 30 min using a Perkin Elmer MPF-3 spectrofluorimeter (excitation $390 \mathrm{~nm}$; emission $480 \mathrm{~nm}$ ). Calibration curves were determined for each peptide.

(b) Uptake of [U-14 C]alanyl-alanine. The method used was essentially the same as that described in (a) above. Radiolabelled peptide stocks $\left(37 \mu \mathrm{Ci} \mathrm{mmol}^{-1} ; 1.37 \mathrm{MBq} \mathrm{mmol}^{-1}\right)$ and unlabelled competitors were prepared in PCG and preincubated at $37^{\circ} \mathrm{C}$. These were added to a cell suspension, also preincubated at $37^{\circ} \mathrm{C}$, to give a working volume of $10 \mathrm{ml}$ and a cell density equivalent to $1 \mathrm{mg}$ dry wt ml-1. Incubation was at $37^{\circ} \mathrm{C}$ with shaking $\left(80\right.$ strokes $\left.\mathrm{min}^{-1}\right)$. Samples of the cell suspension $(1 \mathrm{ml})$ containing the radiolabelled peptide were filtered through Whatman GF/A filters which were then washed with $10 \mathrm{ml} \mathrm{PCG}$ at $25^{\circ} \mathrm{C}$. The filters were dried under infrared illumination, placed in small scintillation vials with $3 \mathrm{ml}$ PCS scintillation cocktail (Amersham) and counted with a Packard Tricarb 3375 Scintillation Counter.

Drug activity assays (a) Minimum inhibitory concentration. A $15 \mathrm{~h}$ YNB culture was used as inoculum for serial dilutions of nikkomycin in YNB giving a final density of $10^{3}$ cells $\mathrm{ml}^{-1}$. After $48 \mathrm{~h}$ at $37^{\circ} \mathrm{C}$ total cell numbers were determined by light microscopy and viable cell numbers by growth of a diluted cell suspension on YNB plates.

(b) Disc diffusion assay: A $15 \mathrm{~h}$ culture was diluted to $10^{6}$ cells $\mathrm{ml}^{-1}$ and $500 \mu \mathrm{l}$ of this suspension was spread over the surface of a $20 \mathrm{ml}$ malt extract plate $\left(2 \%, \mathrm{w} / \mathrm{v}\right.$, agar) which was then incubated at $37^{\circ} \mathrm{C}$ for $30 \mathrm{~min}$. The required drug was absorbed onto a disc ( $6 \mathrm{~mm}$ diameter) of chromatography paper (Whatman $17 \mathrm{Chroma})$ as a solution in either water or dimethylformamide. The discs were dried and then placed onto the prepared plates in conjunction with solvent controls, to allow residual effects of the solvents to be observed. Diffusion of the drug occurred and, after incubation at $37^{\circ} \mathrm{C}$ for $48 \mathrm{~h}$, the diameter of the zone of growth inhibition was determined in comparison with solvent control plates.

Preparation of chitin synthase. The method used was based upon that of Ryder \& Peberdy (1977). A 15 h culture grown on brain heart infusion (Difco) at $37^{\circ} \mathrm{C}$ was harvested by centrifugation at $1500 \mathrm{~g}$ and washed twice with $0.1 \mathrm{M}$-sodium phosphate buffer pH 6.5 containing $10 \mathrm{mM}-\mathrm{MgCl}_{2}$ and $1 \mathrm{mM}$-EDTA (PME buffer). Cells were resuspended in PME ( $1 \mathrm{ml}$ packed cell volume per $0.5 \mathrm{ml}$ buffer) and were broken with an equal volume of $0.45 \mathrm{~mm}$ glass beads in a Braun homogenizer (Melsungen AG, West Germany) with liquid $\mathrm{CO}_{2}$ cooling. The beads were removed by filtration and the whole cells and cell walls sedimented by centifugation at $1500 \mathrm{~g}$. The supernatant was centrifuged at $125000 \mathrm{~g}$ for $40 \mathrm{~min}$ and the pellet resuspended in $3 \mathrm{ml}$ PME. The membrane fraction was incubated with trypsin (bovine pancreas; $50 \mu \mathrm{g} \mathrm{ml}^{-1}$ ) at $25^{\circ} \mathrm{C}$ for $10 \mathrm{~min}$ and a twofold excess of soybean trypsin inhibitor was then added to terminate proteolysis. This suspension was used as a crude chitin synthase preparation.

Chitin synthase assay. The assay medium contained the required concentration of UDP- $N$-acetyl-Dglucosamine; UDP- $N$-acetyl-D-[U-14 C]glucosamine $\left(1 \mu \mathrm{Ci} \mathrm{m}^{-1} ; 37 \mathrm{kBq} \mathrm{ml}^{-1}\right) ; 400 \mathrm{mM}-N$-acetyl-D-glucosamine; PME; competitors in PME; and the membrane suspension in a total volume of $100 \mu \mathrm{l}$. Chitin synthesis was allowed to proceed at $25^{\circ} \mathrm{C}$ and was terminated by the addition of $400 \mu 110 \%(\mathrm{w} / \mathrm{v})$ trichloroacetic acid. The resulting pellet was washed by two cycles of centrifugation and sonication with $1 \%(\mathrm{v} / \mathrm{v})$ acetic acid and finally resuspended in $1 \%$ acetic acid. Incorporated radiolabel was assayed using Instagel scintillant (Packard) and a Searle Mark III 6880 scintillation counter. Radioactivity was related to $N$-acetyl-D-[U-14C]glucosamine incorporated into chitin. The protein concentrations of the membrane fraction were determined by the Lowry method using bovine serum albumin as standard.

Production of mutants. Cells were grown for $12 \mathrm{~h}$ on YNB, harvested by centrifugation ( $1500 \mathrm{~g})$, washed and resuspended in $65 \mathrm{mM}-\mathrm{KH}_{2} \mathrm{PO}_{4}\left(0.5 \mathrm{ml}\right.$ packed cell volume in $\left.10 \mathrm{ml} \mathrm{KH}_{2} \mathrm{PO}_{4}\right)$. A portion $(700 \mu \mathrm{l})$ of this suspension was distributed on a $20 \mathrm{ml} \mathrm{YNB}$ plate and incubated at $37^{\circ} \mathrm{C}$ for $24 \mathrm{~h}$. This process produced singlet blastospores of $C$. albicans which were diluted to $10^{6} \mathrm{ml}^{-1}$ in YNB. This suspension $(15 \mathrm{ml})$ was irradiated for $50 \mathrm{~s}$ with a bactericidal UV lamp (Englehard-Hanovia, Cinderford, UK) from a distance of $30 \mathrm{~cm}$ producing a $0.5 \%$ survival rate. Drug resistant mutants were selected by plating irradiated cells onto $2 \%(\mathrm{w} / \mathrm{v})$ malt extract plates containing $50 \mu \mathrm{g}$ nikkomycin $\mathrm{ml}^{-1}$. After incubation at $37^{\circ} \mathrm{C}$ any viable colonies were picked out and again plated onto malt extract agar containing nikkomycin.

Chemicals. Nikkomycin ( $80 \%$ nikkomycin containing $\mathrm{X}$ and $\mathrm{Z}$ as major components) was a gift from Bayer $\mathrm{AG}$; bacilysin was a generous gift of Professor C. P. Abraham, University of Oxford; UDP- $N$-acetyl-D-[U${ }^{14} \mathrm{C}$ ]glucosamine was purchased from Amersham; [U-14 $\left.\mathrm{C}\right]$ alanyl-alanine $\left(37 \mu \mathrm{Ci} \mathrm{mmol}{ }^{-1}\right)$ was prepared by $\mathrm{P}$. $\mathrm{J}$. McCarthy at the Sandoz Research Institute, Vienna. $m$-F-Phe-Ala-Ala was synthesized by Dr W. D. Kingsbury of Smith Kline and French Laboratories. Fluorescamine (Fluram) was from Roche; remaining chemicals were from Sigma. All amino acid residues were in the L-configuration unless otherwise stated. 


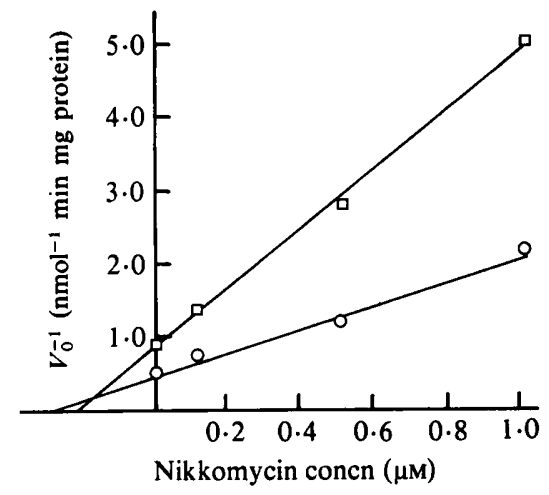

Fig. 1. Effect of nikkomycin on C. albicans 124 (wild-type) chitin synthase. Synthesis of chitin from UDP- $N$-acetyl-D-[U-14 $\mathrm{C}]$ glucosamine was measured in the presence of various concentrations of nikkomycin and at two concentrations of unlabelled UDP- $N$-acetyl-glucosamine $(\square, 0.3 \mathrm{~mm} ; O$, $0.6 \mathrm{mM}$ ). Initial rates of incorporation of radiolabel into chitin were determined in triplicate and plotted according to the method of Dixon (1953).

Table 1. Rate of uptake of specific peptides into wild-type C. albicans and the NIK5 mutant and the potency of these peptides as antagonists of nikkomycin activity against wild-type C. albicans

$\begin{array}{lccc}\text { Peptide } & \begin{array}{c}\text { Antagonism of } \\ \text { nikkomycin action* }\end{array} & \overbrace{\text { Wild-type }}^{\text {Rate of uptake } \dagger} & \text { NIK5 } \\ \text { Ala }_{2} & + & 38 \cdot 0 & 7 \cdot 4 \\ \text { Gly-Tyr } & - & 0 & 0 \\ \text { D-Leu-Gly } & - & 0 & 0 \\ \text { L-Leu-Gly } & + & 32 \cdot 0 & 0 \\ \text { Gly }_{2} & - & 0 & 0 \\ \text { Ala }_{3} & - & 30 \cdot 3 & 41.6 \\ \text { Ala }_{4} & - & 52.6 & 90.9\end{array}$

* At concentrations of $10 \mathrm{~mm}$-peptide and $50 \mu \mathrm{g}$ nikkomycin $\mathrm{ml}^{-1}$.

$\dagger$ As determined by the fluorescamine method from an initial peptide concentration of $0.2 \mathrm{~mm}$. Results are expressed as $\mathrm{nmol} \mathrm{min}^{-1}$ (mg dry wt cells) ${ }^{-1}$.

\section{RESULTS}

Inhibition of chitin synthase. Nikkomycin was a potent inhibitor of growth of Candida albicans. Partial inhibition of growth was observed at $3 \mu \mathrm{g} \mathrm{ml}^{-1}$ with the MIC occurring at $25 \mu \mathrm{g} \mathrm{ml}^{-1}$. It was also found to be a competitive inhibitor of the membrane fraction chitin synthase (Fig. 1) with a $K_{\mathrm{i}}$ of $0.16 \mu \mathrm{M}$ (based on the average molecular weights of the $\mathrm{X}$ and $\mathrm{Z}$ components of the nikkomycin sample).

Effect of growth medium upon nikkomycin activity. The activity of nikkomycin against intact cells was highly medium dependent. In contrast to the MIC of $25 \mu \mathrm{g} \mathrm{ml}^{-1}$ in YNB, the inclusion of $2 \%(\mathrm{w} / \mathrm{v})$ Bacto-peptone in the medium abolished the activity of the drug even at $50 \mu \mathrm{g} \mathrm{ml}^{-1}$ with neither a reduction in the growth rate nor an alteration in morphology. Microscopic examination revealed that the small increase in turbidity observed during incubation of cells in YNB containing nikkomycin was due to the clumping of cells associated with cell enlargement and lysis.

The inclusion of certain defined peptides $(10 \mathrm{~mm})$ in YNB was also found to antagonize the action of nikkomycin (Table 1). This was not the case for all peptides assayed. Ala ${ }_{2}$ and L-LeuGly were antagonistic whereas D-Leu-Gly, Gly 2 , Gly-Tyr, $\mathrm{Ala}_{3}$ and $\mathrm{Ala}_{4}$ showed no such effect.

Rates of peptide uptake. There was a correlation between transported dipeptides $\left(\mathrm{Ala}_{2}\right.$ and LLeu-Gly) and those peptides able to compete with nikkomycin activity (Table 1). A likely explanation of this phenomenon is that nikkomycin was being transported through a system which also transported peptides. Confirmation that competition was at the level of transport 


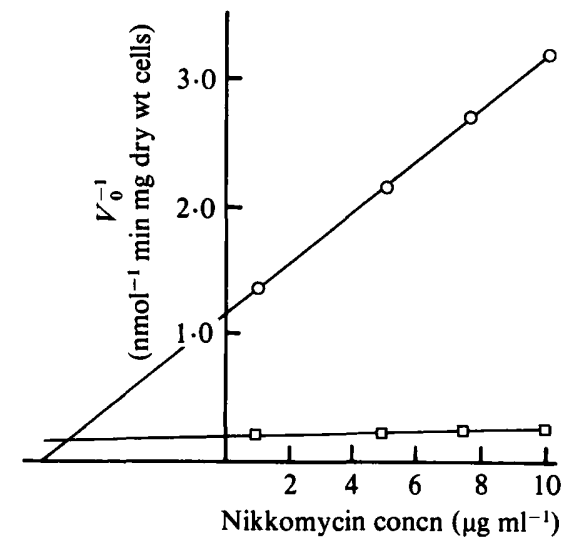

Fig. 2. Effect of nikkomycin on [U-14 C]Ala-Ala incorporation by $C$. albicans 124 (wild-type). Cells were grown in YNB/peptone, harvested, washed and resuspended in PCG. The initial rates of incorporation of $\left[\mathrm{U}^{-14} \mathrm{C}\right] \mathrm{Ala}-\mathrm{Ala}$ were determined in the presence of various concentrations of nikkomycin. Cells were diluted to $1.0 \mathrm{mg}$ dry wt $\mathrm{ml}^{-1}$, and $\left[\mathrm{U}-{ }^{14} \mathrm{C}\right] \mathrm{Ala}-\mathrm{Ala}$ added to a concentration of either $0.1 \mathrm{mM}(\mathrm{O})$ or $0.2 \mathrm{mM}(\square)$. The suspension was incubated at $37^{\circ} \mathrm{C}$ with shaking. Samples $(1 \mathrm{ml})$ were removed at timed intervals and the radioactivity incorporated into cells was determined. Initial rates of incorporation were calculated in triplicate. Mean values are plotted according to the method of Dixon (1953).

\section{Table 2. Effects of various inhibitors on growth of wild-type C. albicans and the NIK5 mutant}

Zones of inhibition were determined by the disc diffusion assay described in the methods section. The quantity of inhibitor applied to the disc is indicated in parentheses.

\section{Drug $(\mu \mathrm{g})$}

Acriflavin (500)

Ethidium bromide (500)

5-Fluorocytosine (500)

Actinomycin D (500)

Cycloheximide (500)

$m$-F-Phenylalanine (500)

Nikkomycin (50)

Polyoxin (crude) (500)

Bacilysin (100)

5-Fluorouracil (50)

Miconazole (50)

Nystatin (20)

$m$-F-Phe-Ala-Ala (30)

$\begin{array}{cc}\begin{array}{c}\text { Diameter of } \begin{array}{c}\text { zone of } \\ \text { inhibition }(\mathrm{mm})\end{array} \\ \text { Wild-type }\end{array} & \text { NIK5 } \\ 15.0 & 15.0 \\ 25.0 & 25.0 \\ 37.0 & 37.0 \\ 10.5 & 10.5 \\ 0.0 & 0.0 \\ 0.0 & 0.0 \\ 30.0 & 0.0 \\ 8.5 & 0.0 \\ 27.0 & 0.0 \\ 10.5 & 10.5 \\ 13.5 & 13.5 \\ 24.0 & 24.0 \\ 20.0 & 11.0\end{array}$

rather than at the target enzyme, chitin synthase, came from the observation that nikkomycin was a competitive inhibitor of [U-14 C]alanyl-alanine uptake by cells $\left(K_{\mathrm{i}}=4.85 \mu \mathrm{g} \mathrm{ml}^{-1}\right.$; Fig. 2). The oligopeptides $\mathrm{Ala}_{3}$ and $\mathrm{Ala}_{4}$ did not show antagonism of nikkomycin activity even though they were transported into $C$. albicans (Table 1).

Resistance to nikkomycin. UV irradiation of C. albicans 124 resulted in the production of six mutants resistant to the effects of nikkomycin in YNB. Each mutant was assayed for its ability to transport $\mathrm{Ala}_{2}$ since this peptide had been shown to utilize the same peptide permease as nikkomycin. One mutant, designated NIK5, was found to have a defect in peptide transport with no apparent alteration of its chitin synthase which remained competitively inhibited by nikkomycin with a $K_{\mathrm{i}}$ of $0.17 \mu \mathrm{M}$. This value was comparable with that of the enzyme prepared from the wild-type.

The susceptibility of $C$. albicans 124 NIK 5 to most antifungal agents was found to be equivalent with that of the wild-type (Table 2). However, cross resistance was observed with 
other peptide antibiotics. NIK 5 was not susceptible to either the dipeptide antibiotic bacilysin or a crude sample of polyoxin containing $10 \%$ active material. Partial cross resistance was observed with the toxic tripeptide $m$-F-Phe-Ala-Ala although the susceptibility of $C$. albicans 124 to this peptide was also low.

Peptide uptake by C. albicans 124 NIK5. The mutant was assayed for its ability to transport the peptides previously used (Table 1). Although its capacity to transport $\mathrm{Ala}_{2}$ and L-Leu-Gly was greatly reduced or abolished, the rate of transport of $\mathrm{Ala}_{3}$ and $\mathrm{Ala}_{4}$ was increased when compared to those rates obtained with the wild-type.

\section{DISCUSSION}

In common with its mode of action against other fungi such as Mucor rouxii (Dahn et al., 1976) nikkomycin prevented growth of $C$. albicans through inhibition of the enzyme chitin synthase. However, its activity was antagonized by either bacto-peptone or certain defined peptides, an effect that has also been observed with polyoxin A activity against Alternaria kikuchiana (Hori et al., 1977). Two explanations of peptide antagonism appeared likely: firstly, competition at the target enzyme, chitin synthase, and secondly an interaction at the level of transport into the cell. Competition at the level of transport would not be observed if the peptide/drug interaction was occurring solely at the target site. Studies of interactions between polyoxin and a chitin synthase preparation from $A$. kikuchiana (Hori et al., 1977) have shown no competition with peptides. As a peptide-specific permease had previously been demonstrated in C. albicans (Logan et al., 1979; Davies, 1980) it was possible that nikkomycin was entering the cells via such a system. The competitive inhibition of [ $\left.\mathrm{U}^{-14} \mathrm{C}\right] \mathrm{Ala}-\mathrm{Ala}$ incorporation exerted by nikkomycin demonstrates that transport of peptides and peptide-nucleosides occurs through a common permease in this organism.

Studies were undertaken to compare the ability of peptides to antagonize nikkomycin by examining their relative uptake rates. As would be expected, non-transported peptides were unable to inhibit nikkomycin activity while the transported dipeptides $\mathrm{Ala}_{2}$ and L-Leu-Gly were effective competitors. Stereospecificity was evident in comparing the antagonistic activity of $D-$ Leu-Gly and L-Leu-Gly. This again indicates a specific site of competition rather than a nonspecific effect and agrees with previous studies which indicated that dipeptide uptake is highly stereospecific (Davies, 1980). Interestingly the oligopeptides $\mathrm{Ala}_{3}$ and $\mathrm{Ala}_{4}$ were transported at a significant rate and yet did not antagonize nikkomycin activity. Sarthou et al. (1983) have reported preliminary kinetic evidence which suggests the presence of multiple peptide permeases in this organism. It is therefore possible that $\mathrm{Ala}_{3}$ and $\mathrm{Ala}_{4}$ were transported via a system separate from that through which nikkomycin entered.

Resistance to nikkomycin may arise through a number of mechanisms including alterations in the target enzyme or the peptide permease. Only a single report of an altered chitin synthase leading to drug resistance exists involving polyoxin D resistance in Schizophyllum commune (MacGruder, 1979). There have been no previous reports of mutations leading to alteration of the $C$. albicans peptide permease. However, such instances in $S$. cerevisiae lead to a total loss of peptide transport capacity (Marder et al., 1978; Nisbet \& Payne, 1979a). It was felt that a mutation in the peptide permease leading to nikkomycin resistance would produce further information concerning the nature of this system. However, of the six drug-resistant mutants produced only one (NIK5) showed such a defect. The nature of the mutation in the remaining variants is being elucidated, however, it is possible that these have alterations in chitin synthase or in the hydrolytic system which could produce nikkomycin resistance.

Initial studies of peptide uptake in NIK 5 showed only a defect in dipeptide transport while the rate of oligopeptide uptake was increased. Such an effect appears to be due to an overall increase in the activity of a second (oligopeptide) permease in response to the peptonecontaining growth medium employed in transport studies. The loss of dipeptide transport was confirmed by the cross resistance observed between nikkomycin and both bacilysin and a crude sample of polyoxin. That tripeptide uptake was, to some extent, separate from dipeptide uptake was confirmed by the susceptibility of NIK 5 to the toxic tripeptide $m$-F-Phe-Ala-Ala. MIC 
values for the wild-type and variant could not be determined due to the apparently low susceptibility of this strain when compared with others (Kingsbury et al., 1983).

The present study indicates that nikkomycin is able to enter the cell via a system with high affinity for dipeptides. The nikkomycin used consisted of dipeptide nikkomycins $\mathrm{X}$ and $\mathrm{Z}$ and is therefore consistent with the argument that dipeptides share a common transport system. Inhibition of growth arises from competition at the target enzyme, chitin synthase, as nikkomycin is an analogue of the natural substrates. The fact that nikkomycin resistance has apparently arisen through a defect in peptide transport indicates the presence of at least two peptide permeases in this organism, system I having high affinity for dipeptides including the dipeptide nikkomycins, and system II having high affinity for oligopeptides. Studies are currently in progress to define further the substrate specificities of the two systems.

This work was funded by a SERC-CASE studentship to P. J. M. between the Sandoz Research Institute, Vienna, Austria, and the University of Kent, England. We sincerely thank Dr H. Nesvadba of the Sandoz Research Institute for his patience and advice concerning the synthesis of the $\left[\mathrm{U}-{ }^{14} \mathrm{C}\right] \mathrm{Ala}-\mathrm{Ala}$. The use of facilities at Pfizer Central Research is gratefully acknowledged.

\section{REFERENCES}

Dahn, U., Hagenmaier, H., Konig, W. A., Wolf, G. \& ZAHNER, H. (1976). Stoffwechselprodukte von mikroorganismen 154 Mitteilung. Nikkomycin ein neuer Hemmstoff der Chitinsynthase bei Pilzen. Archives of Microbiology 197, 143-160.

Davies, M. D. (1980). Peptide uptake in Candida albicans. Journal of General Microbiology 121, 181186.

Dixon, M. (1953). The determination of enzyme inhibition constants. Biochemical Journal 55, 170 175.

Hori, M., KaKiki, K. \& Misato, T. (1977). Antagonistic effect of dipeptides of the uptake of polyoxin A by Alternaria kikuchiana. Journal of Pesticide Science 2, 139-149.

Kingsbury, W. R., Boehm, J. C., Mehta, R. J. \& GraPPEL, S. F. (1983). Transport of antimicrobial agents using peptide carrier systems: anticandidal activity of $m$-fluorophenylalanyl-peptide conjugates. Journal of Medicinal Chemistry 26, 1725-1729.

LOGAN, D. A., BeCKER, J. M. \& NAIDER, F. (1979). Peptide transport in Candida albicans. Journal of General Microbiology 114, 179-186.

MacGruder, G. C. (1979). The chitin synthetase enzyme of Schizophyllum commune 'wild type' and the mutant 'streak'. PhD dissertation, University of Missouri, Rolla, Mo., USA.

Marder, R., Rose, B., Becker, J. M. \& NaIder, F. (1978). Isolation of a peptide transport-deficient mutant of yeast. Journal of Bacteriology 136, 11741177.

Nisbet, T. M. \& PAYNe, J. W. (1979a). Specificity of peptide uptake in Saccharomyces cerevisiae and isolation of a bacilysin-resistant, peptide transport deficient mutant. FEMS Letters 7, 193-196.

Nisbet, T. M. \& PAYne, J. W. (1979 b). Peptide uptake in Saccharomyces cerevisiae. Characteristics of a transport system shared by dipeptides and oligopeptides. Journal of General Microbiology 115, $127-$ 133.

RYDER, N. S. \& Peberdy, J. F. (1977). Chitin synthase in Aspergillus nidulans: Properties and proteolytic activation. Journal of General Microbiology 99, 6976.

Sarthou, P., Gonneau, M. \& Le Goffic, F. (1983). Photoaffinity inhibition of peptide transport in yeast. Biochemical and Biophysical Research Communications 110, 884-889. 